\title{
PREDICTION OF THE EFFECTS OF SOIL WATER STRESS ON GRAIN YIELD AND RADIATION USE EFFICLENCY OF RICE (ORYZA SATIVA L.) USING A SIMULATION MODEL
}

\author{
W.A.J.M. DE COSTA \\ Department of Crop Science, Faculty of Agriculture, University of Peradeniya, Peradeniya.
}

(Received: 30 July 1997; accepted: 03 July 1998 )

\begin{abstract}
Drought is the major abiotic stress factor which causes yield losses of rice in Sri Lanka. The present study quantified the effects on rice yield of two effects of drought, namely reduction of leaf area and modification of photosynthesis, respiration and assimilate partitioning characteristics. A process-based model which simulated radiation interception, canopy photosynthesis, respiration and assimilate partitioning was used to independently analyse the above effects of drought. A soil water sub-model which computed the daily soil water content (SWC) through a water balance was used to quantify the onset and magnitude of drought. The model was run for irrigated and water-stressed rice crops for a 12-year period (1985-1996) using daily meteorological data from Maha Illuppallama in the Low Country Dry Zone (DL $\left.L_{1}\right)$.
\end{abstract}

Simulation of SWC showed that in $\mathrm{DL}_{1}$, during the maha season, water stress ( $<60 \%$ available water) did not occur until the beginning of grain filling stage, whereas during the yala season it occurred at or before the end of the vegetative stage. When both leaf area index (LAI) and photosynthetic characteristics were reduced by water stress, the simulated yield reductions were $3-64 \%$ in maha and $23-81 \%$ in yala. Reduction of LAI accounted for $36-100 \%$ of the above yield reductions while modification of photosynthetic characteristics contributed $0-64 \%$. Contribution of reduced LAI was greater in a majority (19 out of 24) of the seasons. Meanwhile, water stress reduced the radiation use efficiency (i.e. biomass produced per unit of radiation intercepted) of rice by $1-73 \%$ to which the greater contribution ( $27-100 \%$ ) came from the reduction of photosynthetic characteristics.

It is concluded that to achieve higher rice yields under the type of drought encountered in $\mathrm{DL}_{1}$, mechanisms of maintaining a higher leaf area even under water stress (i.e. osmotic adjustment, lower cell wall extensibility and threshold turgor) should be incorporated through breeding. In addition, greater stomata] sensitivity to water stress should be incorporated as a reversible mechanism of surviving possible periods of severe water deficits.

Keywords: Drought, radiation use efficiency, rice, simulation modelling, water stress.

\section{INTRODUCTION}

Rice is the most important agricultural crop for Sri Lanka because it is the staple food of almost the entire population of the country. It is estimated that the

This paper is based on a presentation made at the Fifth Annual Staff Research Sessions of the Faculty of Agriculture, University of Peradeniya, Peradeniya on 12 July 1997. 
national average rice yield needs to be raised from the current average of $3.5 \mathrm{t} \mathrm{ha}^{-1}$ to $5 \mathrm{t} \mathrm{ha}^{-1}$ to meet the increasing demand created by the current rate of population increase. ${ }^{1}$ Significant yield losses due to drought has been a major constraint in increasing current rice yields in both Sri Lanka and other ricegrowing areas in the world.,3 Much of the improved technology in rice cultivation during the past three decades have almost entirely been directed towards yield improvement of irrigated rice.4, However, one-fourth of the world's total rice area $^{3}$ and one-third of Sri Lanka's rice area are in rainfed lowlands or uplands which are frequently subjected to water deficits of varying intensities and durations causing significant yield losses. ${ }^{6}$ Even the irrigated rice areas have experienced drought during recent times because of the scarcity of irrigation water due to lack of rainfall in the major catchment areas. Therefore, breeding of drought tolerant rice varieties should be one of the priority areas of research directed towards raising current rice yields.

Drought affects several steps of the growth and yield formation process of rice and the observed yield reduction is the integration of all effects on many different processes. Breeding for drought tolerance requires specific, quantitative information on different physiological responses to drought and their respective contribution to the observed yield decline due to drought. This would enable identification of critical responses and characteristics of drought tolerance which could form the basis of subsequent selection and hybridisation. The present study analyses the growth and yield formation of rice under both irrigated and drought conditions and quantifies the contribution to yield reduction of two major effects of drought, namely reduction of leaf area ${ }^{i}$ and carbon assimilation. ${ }^{5,9}$ In addition, influence of the above effects of drought on radiation use efficiency -RUE- (i.e. amount of biomass accumulated per unit of radiation intercepted) is also quantified. RUE is an important determinant of grain yield because it determines the maximum amount of biomass available to be partitioned to grains.

\section{METHODS AND MATERIALS}

The method of dynamic simulation modelling ${ }^{10}$ was used to simulate the performance of irrigated (i.e. non-water stressed) and rainfed (i.e. waterstressed) rice. The basic model (Fig. 1) was developed for an irrigated rice crop. Effects of water stress were simulated by varying the relevant parameters and processes of the basic model on the basis of daily soil water content estimated from a water balance sub-model. 


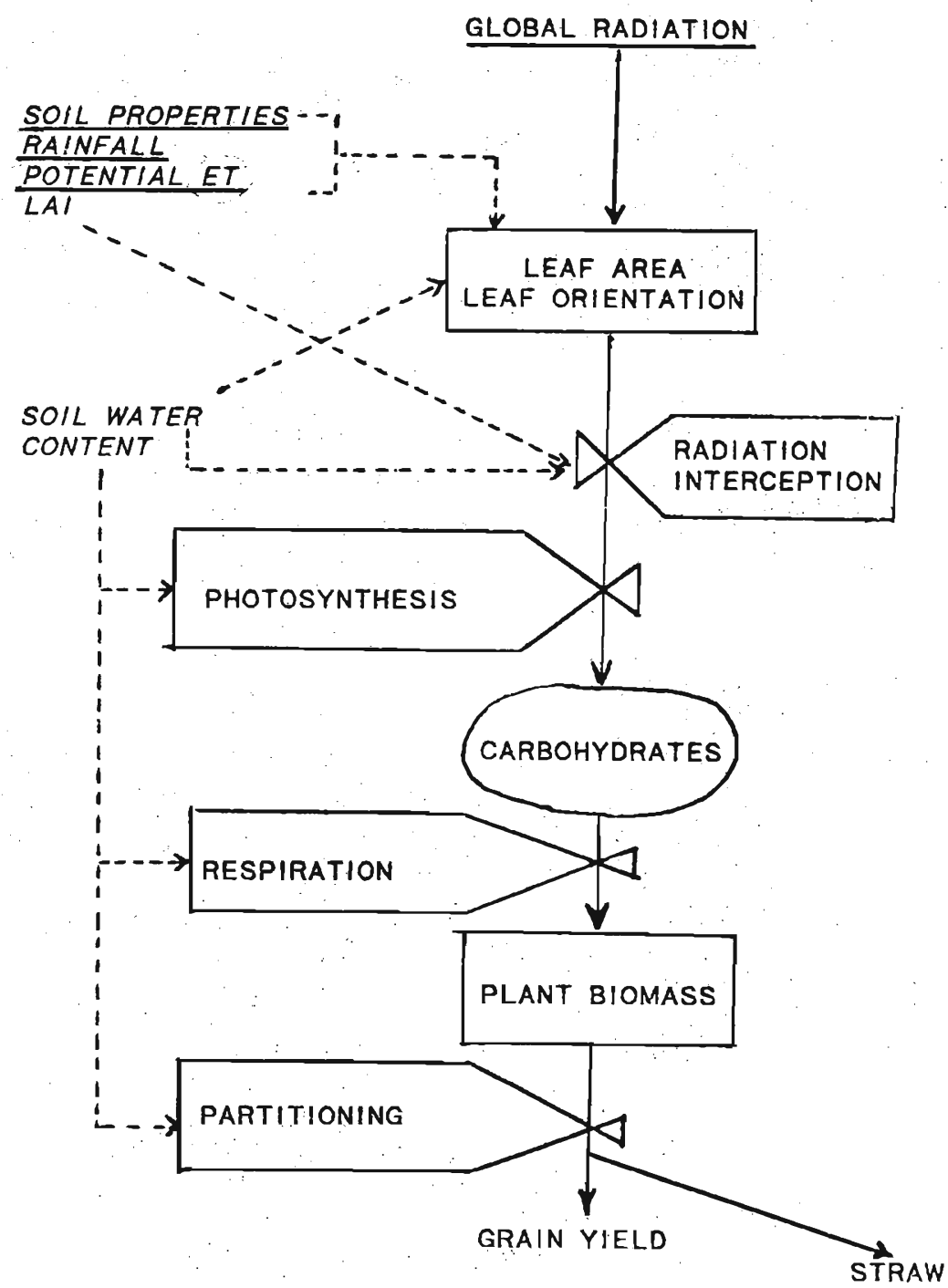

Figure 1: Relational diagram of the basic model. Rectangles represent quantities (state variables); valve symbols - rates; circles - auxiliary variables; underlined variables external driving variables; full lines - flow of materials; dashed lines - effects.

\section{Overview of the basic model}

The model is primarily driven by incoming radiation which is intercepted by the leaf canopy and used in photosynthesis. Part of the carbohydrates produced by photosynthesis is converted to plant biomass and the rest is used in respiration which provides the energy for synthesis of new biomass and the maintenance of existing biomass. Synthesised biomass is finally partitioned into grains and straw with the proportions of partitioning varying according to the developmental stage. 
The simulations were carried out for a 12-year period from maha, 1984/85 to yala, 1996 using daily meteorological data at Maha Illuppallama. This location is representative of the low-country dry zone $\left(\mathrm{DL}_{1}\right)$ which is the major rice-growing area of Sri Lanka." This agroclimatic zone also contains a major portion of drought-prone rice land.

\section{Description of model components}

(a) Total crop durations:

Following common farmer practice in the low-country dry zone, a 4-month rice variety was used for simulation during the maha season (i.e. November to March) and a $3 \frac{1}{2}$-month variety was used for the yala season (i.e. April to July). The sowing dates for maha and yala seasons were 15, November and 10, April respectively.

\section{(b) Developmental stages and their duration:}

A rice crop consists of three developmental stages, namely, vegetative, reproductive and grain filling. The vegetative stage is defined as the duration from germination to panicle initiation. The period from panicle initiation to heading is the reproductive stage and that from heading to maturity is the grain filling stage. In a 120-day variety, durations of the three successive stages are 60,30 and 30 days respectively. ${ }^{12}$ Durations of the reproductive and grain filling stages are similar in a $3 \frac{1}{2}$-month (105-day) variety while a shorter, 45-day vegetative stage constitutes the difference in total crop duration between the two varieties..$^{12}$

\section{(c) Incoming radiation:}

The daily global radiation levels (in $\mathrm{MJm}^{-2} \mathrm{~d}^{-1}$ ) for the simulation period (i.e. from October, 1984 to August, 1996) were computed from the measured daily values of sunshine duration (hours) by using a set of meteorological equations ${ }^{13}$ and an empirical equation." It was assumed that the daily total of global radiation energy is distributed according to a sine curve over the length of each day. The total day length was divided into $0.05 \mathrm{~h}(3 \mathrm{~min})$ time steps and the irradiance (I), in terms of PAR, for a given time step was calculated as:

$$
\mathrm{I}=(\pi \mathrm{S} / 2 \mathrm{~T})^{*} \mathrm{SIN}(\pi \mathrm{t} / \mathrm{T})
$$

where: $S$ is the daily global radiation in $\mathrm{MJm}^{-2} \mathrm{~d}^{-1}$;

$\mathrm{T}$ is day length; and

$t$ is the time after sunrise. 
It was assumed that $50 \%$ of the energy content in global radiation was contained within the PAR wavelength range. ${ }^{15}$

(d) Interception of incoming radiation:

Interception of incoming radiation by a crop canopy and the distribution of intercepted radiation among the canopy leaf area determine the amount of energy available for photosynthesis and yield formation. Radiation interception by the rice canopy was quantified by the Monsi \& Saeki's ${ }^{16}$ application of Beer's law for penetration of radiation into plant canopies given as follows:

$$
I_{L}=I e^{-k L}
$$

where: I is the intensity of radiation (i.e. irradiance) incident on top of the canopy;

$\mathrm{I}_{\mathrm{L}}$ is the irradiance on a horizontal plane of the canopy below a leaf area index of $\mathrm{L}$; and

$\mathrm{k}$ is the canopy light extinction coefficient which is mainly determined by the orientation of leaves relative to the direction of incident radiation.

Therefore, the amount of incident radiation intercepted by a canopy would be:

$$
\mathrm{I}-\mathrm{I}_{\mathrm{L}}=\mathrm{I}\left(1-\mathrm{e}^{-\mathrm{L}} \mathrm{L}\right)
$$

(e) Distribution of intercepted radiation:

The distribution of the above amount of intercepted radiation over the canopy leaf area needs to be quantified in order to compute canopy photosynthesis. Out of several different methods available, the approach used by Monteith ${ }^{17}$ was used in the present study: Here, the canopy is divided into two categories as: (i) 'Sunlit' foliage which is the area of leaves directly-illuminated by incoming radiation penetrating into the canopy; and (ii) 'Indirectly-lit' foliage which is the area of leaves receiving radiation which has been intercepted once by the 'sunlit' foliage and subsequently transmitted to the lower leaf layers. Monteith \& Unsworth ${ }^{18}$ showed that the sunlit leaf area $\left(\mathrm{L}_{0}\right)$ and indirectly-lit leaf area $\left(\mathrm{L}_{1}\right)$ can be computed by the following equations:

$$
\mathrm{L}_{0}=\left(1-\mathrm{e}^{-\mathrm{k} L}\right) / \mathrm{k}
$$

and

$$
L_{1}=L_{0}-\left(L * e^{-k L}\right)
$$

It can be shown that for large canopies with high $L$, both $L_{0}$ and $L_{1}$ tend to a limiting value of $1 / \mathrm{k}$. 
(f) Leaf area index and light extinction coefficient of rice canopies:

The variation of leaf area index $(\mathrm{L})$ of a crop, from germination up to the point of reaching maximum $\mathrm{L}$, can be quantified by the logistic function. ${ }^{19}$ Therefore, in the absence of water stress, the variation of $L$ up to the point of maximum $L$ of the simulated rice crops were specified by the following equations:

For the 4-month variety:

$$
L=7.57\left[\left(1+e^{4.30 \cdot-0.116 d) \cdot 1]}\right.\right.
$$

For the $3 \frac{1}{2}$-month variety:

$$
\mathrm{L}=7.03\left[\left(1+\mathrm{e}^{5.11 \cdot 0.1700)-1]}\right.\right.
$$

where, $d$ is the number of days after sowing.

The times of achieving maximum $L$ were specified as 75 and 60 days after sowing (DAS) respectively for the 4 -month and $3 \frac{1}{2}$-month varieties. In both varieties, the maximum $L$ values were maintained for the next 35 -day period after which $L$ decreased to a value of 2 at maturity according to the following linear equations:

For 4-month variety:

$$
L=68.84-0.557 d
$$

and for $3 \frac{1}{2}$-month variety:

$$
\mathrm{L}=54.82-0.503 \mathrm{~d}
$$

The variation patterns specified by equations $6-9$, were based on the observed patterns of $\mathrm{L}$ for rice crops grown in the low-country dry zone (de Costa, Unpublished).

The light extinction coefficient $(\mathrm{k})$ of both rice varieties was specified as 0.4 which is representative of the new high-yielding varieties with dwarf stature and erect leaves. ${ }^{12}$

\section{(g) Photosynthetic light response:}

The instantaneous gross photosynthetic rate $(\mathrm{P})$ of a unit area of leaf in the canopy is primarily determined by the irradiance per unit leaf area (i). The variation of $\mathrm{P}$ with I (Fig. 2) can be described by an asymptotic exponential equation as follows:

$$
P=P_{m}\left(1-e^{-(l i-c) / B)}\right)
$$


where: $P_{m}$ is maximum light-saturated gross photosynthetic rate per unit leaf area;

B is the irradiance per unit leaf area (i) at which $\mathrm{P}_{m}$ is reached at initial, maximum quantum efficiency (a); and

$\mathrm{c}$ is the light compensation point (i.e. the light intensity at which photosynthesis becomes zero).

The $\mathrm{P}_{n}$ of rice at current $\mathrm{CO}_{2}$ and temperature levels and in the absence of water stress was specified at $32 \mu \mathrm{mol} \mathrm{CO} \mathrm{m}^{-2} \mathrm{~S}^{-1}{ }^{12}$ The value of $\mathrm{B}$ is determined by $\mathrm{P}_{\mathrm{m}}$, a and the light compensation point (LCP) as:

$$
\mathrm{B}=\left(\mathrm{P}_{\mathrm{m}}+\mathrm{a} \mathrm{LCP}\right) / \mathrm{a}
$$

In the absence of water stress, a B value of $579.33 \mu \mathrm{mol}$ PAR m.2 $\mathrm{s}^{-1}$ was calculated based on the values of $0.042 \mathrm{~mol} \mathrm{CO}_{2}(\mathrm{~mol} \mathrm{PAR})^{-1}$ for $\mathrm{a}^{20}$ and $7.58 \mu \mathrm{mol}$ $\mathrm{PAR} \mathrm{m}^{-2} \mathrm{~S}^{-1}$ for $\mathrm{LCP}^{12}$ of rice.

Therefore, the gross photosynthetic rates per unit leaf area of sunlit $\left(\mathrm{P}_{0}\right)$ and indirectly-lit $\left(\mathrm{P}_{1}\right)$ foliage can be computed using eq. 10 as:

For sunlit leaves:

$$
P_{0}=P_{m}\left(1-e^{-|k / / 3|)}\right.
$$

For indirectly-lit leaves:

$$
\mathrm{P}_{1}=\mathrm{P}_{\mathrm{m}}\left(1-\mathrm{e}^{-\mid 0.24 k 1 / 3)}\right)
$$

As the respective areas of both sunlit- and indirectly-lit leaves tend to a limiting value of $1 / \mathrm{k}$ at high $\mathrm{L}$ (eqs. 4 and 5), the irradiance per unit leaf area (i) becomes $\mathrm{kI}$ and $0.14 \mathrm{kI}$ respectively. The constant 0.14 is the transmission coefficient $^{18}$ which represents the fraction of intercepted radiation transmitted through a sunlit leaflayer to be subsequently intercepted by an indirectly-lit leaf area.

\section{(h) Canopy photosynthesis:}

The instantaneous canopy gross photosynthesis $\left(\mathrm{P}_{\mathrm{c}}\right)$ for a given time step of $0.05 \mathrm{~h}$ ( $3 \mathrm{~min})$ was computed as the sum of gross photosynthesis of sunlit and indirectly-lit foliage:

$$
\mathrm{P}_{\mathrm{c}}=\left(\mathrm{P}_{0} \cdot \mathrm{L}_{0}\right)+\left(\mathrm{P}_{1} \cdot \mathrm{L}_{1}\right)
$$


The $\mathrm{P}_{\mathrm{c}}$ values computed in $\mu \mathrm{mol} \mathrm{CO}_{2} \mathrm{~m}^{-2} \mathrm{~s}^{-1}$ were converted to assimilated carbohydrates $\left(\mathrm{P}_{\text {Сн }}\right)$ in $\mathrm{g}\left[\mathrm{CH}_{2} \mathrm{O}^{1} \mathrm{~m}^{* 2} \mathrm{~s}^{-1}\right.$ as:

$$
\mathrm{P}_{\mathrm{CHO}}=\mathrm{P}_{\mathrm{c}} \times 30
$$

indicating that each mole of $\mathrm{CO}_{2}$ used in photosynthesis would produce $30 \mathrm{~g}$ of carbohydrates as assimilates.

\section{(i) Respiration:}

Part of the carbohydrates assimilated by gross photosynthesis would be used in producing plant biomass consisting of various biochemical compounds (i.e. sugars, cellulose, proteins, lipids etc.). The rest would be utilised as a substrate for respiration to generate the energy required for synthesis of new plant biomass (i.e. growth respiration) and for maintaining the structure and functioning of the existing biomass (i.e. maintenance respiration). In rice, the fraction of growth respiration in total respiration is high during the vegetative and reproductive stages. On the other hand, during the grain filling period, the growth respiration decreases and the maintenance component of total respiration increases. ${ }^{12.21}$ However, despite the above variation of the relative contributions of growth and maintenance components, Yamaguchi ${ }^{22}$ observed that total respiration is a relatively constant fraction of gross photosynthesis.

In the present study, for irrigated rice, a value of 0.3 was specified as the fraction of gross photosynthesis used for total respiration $(R)$ during the vegetative and reproductive stages. A corresponding value of 0.4 was used for $R$ during the grain filling period. These values were based on a survey of values used by other workers. ${ }^{17,21}$

(j) Net photosynthesis and biomass accumulation:

The net increase of biomass (i.e. net photosynthesis $-\mathrm{P}_{1}{ }^{-}$) for a given time step can be computed as:

$$
P_{n}=(1-R) P_{\text {cro }}
$$

The computed $P_{11}$ values of each $0.05 \mathrm{~h}$ time step were integrated over the total day length to compute the daily accumulation of crop biomass.

(k) Partitioning of biomass into grains:

Carbohydrates are partitioned into rice grains from two sources. The first source is current photosynthesis during the grain-filling stage. All carbohydrates synthesised from photosynthesis during the grain-filling stage are translocated 
to grains ${ }^{12,23}$. The second source of carbohydrates to the filling grains is the translocated assimilates which had been produced during the vegetative and reproductive stages and stored in vegetative parts, i.e. 'pre-heading storage'. According to Cock \& Yoshida ${ }^{24}, 68 \%$ of the biomass accumulated before the onset of grain filling is translocated to grains. However, when rice crops are grown with adequate supplies of water and nutrients and without experiencing extremely high or low temperatures, the percentage of pre-heading storage translocated to grains is generally lower than 68\%.12. Therefore, in the present study, for simulations under irrigated conditions, it was assumed that $30 \%$ of carbohydrates assimilated during each day of vegetative and reproductive stages are ultimately translocated to grains. Hence, the final grain yield is the sum of carbohydrates from current photosynthesis and pre-heading storage. This final grain yield was adjusted to a moisture content of $14 \%$ which is representative of the level of moisture in grains at harvest.

\section{Water balance sub-model}

This sub-model was developed to compute the daily soil profile water content. (SWC). It was assumed that the soil belonged to the group Low Humic Gley (LHG) which is the predominant rice soil in Sri Lanka. ${ }^{25}$ The soi] was assumed to be at field capacity at the beginning of the season. This agrees with the rea] farming conditions because the majority of rice in Sri Lanka is planted on wet, puddled soil.

Seasonal variation of SWC was computed by daily soil water balance by accounting for the major inputs and outputs of water.

$$
\mathrm{SWC}_{\mathrm{n}}=\mathrm{SWC}_{\mathrm{n}-1}+\mathrm{RF}-(\mathrm{T}+\mathrm{E})
$$

where, the subscripts $\mathrm{n}$ and $\mathrm{n}$ - 1 refer to the corresponding SWC values on a given day $\mathrm{n}$ and on the previous (i.e. $\mathrm{n}-1$ ) day. Daily rainfall ( $\mathrm{RF}$ ) was obtained from meteorological data for Maha Illuppallama during the 12-year period used for simulation. Crop transpiration (T) and evaporation from the soil (E), which are the major sources of water loss from a rice soil, were estimated on the basis of potential evaporation ( $\mathrm{E}_{\mathrm{o}}$ ) and crop leaf area index (L). At field capacity, both $\mathrm{T}$ and $\mathrm{E}$ are at their respective maxima (i.e. $\mathrm{T}_{m}$ and $\mathrm{E}_{m}$ ) as determined by $\mathrm{E}_{n}$ and $\mathrm{L}$ as:

$$
\begin{aligned}
& \mathrm{T}_{\mathrm{m}}=\mathrm{E}_{\mathrm{n}}\left[1-\mathrm{e}^{-0.6 \mathrm{~L}}\right] \\
& \mathrm{E}_{\mathrm{m}}=\mathrm{E}_{\mathrm{o}} \mathrm{e}^{-0.6 \mathrm{~L}}
\end{aligned}
$$

Here, $T_{n}$ is a function of the atmospheric evaporative demand (i.e. $E_{n}$ ) and the area of evaporating canopy surface (i.e. L) and increases with increasing $L^{26}$ 
up to a certain limit. On the other hand, $\mathrm{E}_{\mathrm{n}}$ decreases with increasing $\mathrm{L}$ because of increased shading of the soil surface. ${ }^{27}$

When the SWC is below field capacity, both $\mathrm{T}$ and $\mathrm{E}$ are reduced from their respective maxima depending on the prevailing SWC. E was assumed to decrease linearly with proportion of available water as:

$$
\mathrm{E}=\mathrm{E}_{\mathrm{m}}\left(\mathrm{SWC}-\mathrm{SWC}_{\mathrm{a}}\right) /\left(\mathrm{SWC}_{\mathrm{fc}}-\mathrm{SWC}_{\mathrm{a}}\right)
$$

where, SWC is the current soil water content and the subscripts fc and a refer to the respective SWC at field capacity and air-entry point. ${ }^{26}$

Transpiration was assumed to proceed at the maximum rate $T_{m}$ until a critical SWC is reached. In the present model, the critical SWC (i.e. SWC for $_{i, 1}$ rice was taken to be $60 \%$ available water. ${ }^{28}$

Therefore, within the range between $\mathrm{SWC}_{\mathrm{rc}}$ and $\mathrm{SWC}_{\mathrm{cr}}, \mathrm{T}=\mathrm{T}_{\mathrm{m}}$.

When $\mathrm{SWC}_{\mathrm{cr}}>\mathrm{SWC}>\mathrm{SWC}_{\mathrm{pwp}}$ (i.e. $\mathrm{SWC}$ at permanent wilting point), $\mathrm{T}$ was assumed to decline linearly with SWC as:

$$
\mathrm{T}=\mathrm{T}_{\mathrm{m}}\left(\mathrm{SWC}-\mathrm{SWC}_{\mathrm{pwp}, \mathrm{p}}\right) /\left(\mathrm{SWC}_{\mathrm{cr}}-\mathrm{SWC}_{\mathrm{pww}}\right)
$$

\section{Simulation of growth and yield formation of rice under water stress}

By appropriate modification of the basic model, three situations of water stress were simulated: (a) Leaf area index (L) is reduced by water stress, but photosynthesis, respiration and assimilate partitioning are unaffected; (b) Photosynthesis, respiration and partitioning are modified by water stress, but Lis unaffected; (c) Both sets of characteristics are affected by water stress.

In stress situations (a) and (c), L was adjusted according to the prevailing SWC as computed by the soil water sub-model:

$$
\mathrm{L}_{\mathrm{s}}=\mathrm{L}_{\mathrm{u}} \cdot \mathrm{A}
$$

where, $L_{s}$ and $L_{v}$ are the respective stressed and unstressed leaf area indices and $\mathrm{A}$ is an adjustment factor. When $\mathrm{SWC}$ was above $\mathrm{SWC}_{\mathrm{r}}, \mathrm{A}$ was equal to 1 . For $\mathrm{SWC}_{c r}>\mathrm{SWC}>\mathrm{SWC}_{p w p}$, A decreased linearly with decreasing $\mathrm{SWC}$ as:

$$
\mathrm{A}=1-\left[\left(\mathrm{SWC}_{\mathrm{cr}}-\mathrm{SWC}\right) /\left(\mathrm{SWC}_{\mathrm{cr}}-\mathrm{SWC}_{p w p}\right)\right]
$$

The response of photosynthesis to water stress was quantified by varying the parameters of the light response curve (Fig. 2) with SWC. Both maximum 
light-saturated photosynthetic rate $\left(\mathrm{P}_{\mathrm{m})}\right.$ and initial, maximum quantum efficiency $(a)$ decrease with water stress. ${ }^{29}$ These decreases were simulated by a linear decrease of $\mathrm{P}_{\mathrm{m}}$ and $a$ when the SWC decreases below $\mathrm{SWC}_{\mathrm{cr}} . \mathrm{P}_{\mathrm{m}}$ and $a$ were assumed to remain at un-stressed levels when the $\mathrm{SWC}$ was above $\mathrm{SWC}_{c r}$. The light compensation point (LCP) increases with decreasing SWC ${ }^{20}$. This was simulated by a linear decrease of LCP at $\mathrm{SWC}<\mathrm{SWC}_{\mathrm{cr}}$. The light saturation point (B) was determined by the respective variations of $\mathrm{P}_{m}, a$ and LCP according to eq. 11 .

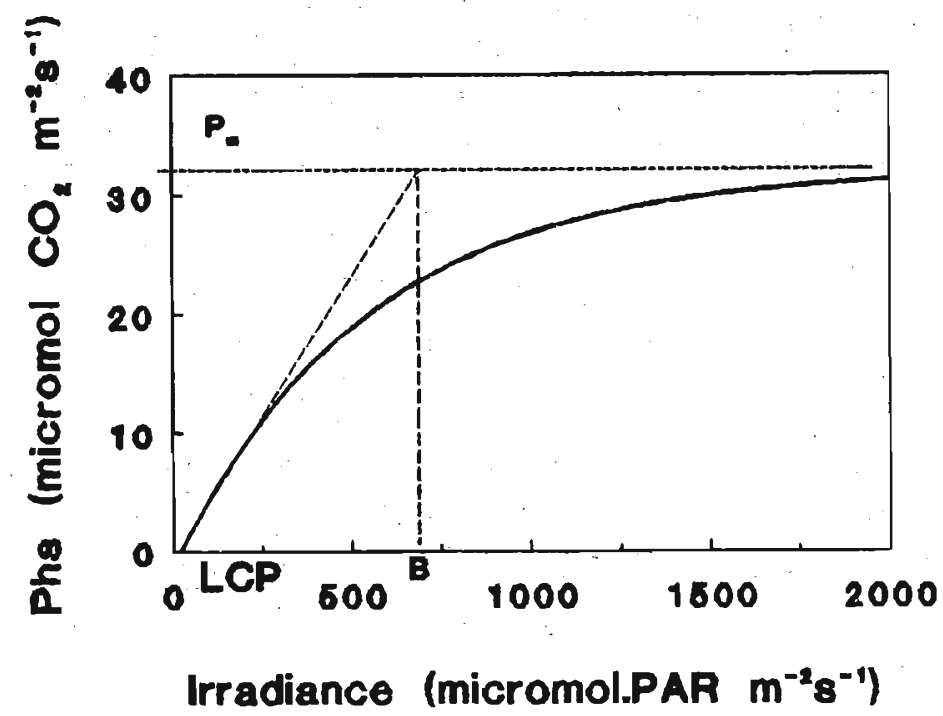

Figure 2: Photosythetic light response curve of rice in the absence of water stress.

Phs- Gross photosynthetic rate. See text for explanation of symbols.

Although the absolute level of respiration decreases with water stress, the decrease of respiration is proportionately less than the decrease of $\mathrm{P}_{11}{ }^{30,31}$ Therefore, the fraction of photosynthesis used for respiration $(R)$ increases with water stress. This was simulated by assuming a linear increase of $\mathrm{R}$ with SWC $<\mathrm{SWC}_{\mathrm{cr}}$. The upper limit of this increase of $\mathrm{R}$ was fixed at a maximum of 0.5 for the vegetative and reproductive stages and at 0.6 for the grain filling period. This fraction includes both the day and night respiration.

Water stress also alters the pattern of assimilate partitioning to grains, with the contribution from pre-heading storage increasing under water stress ${ }^{12}$. This was simulated by increasing the fraction of pre-heading assimilates translocated grains up to $40 \%$.

It was further assumed that crop duration and light extinction coefficient do not change with water stress. All simulations were carried out with a time step of 0.05 h (i.e. $3 \mathrm{~min}$ ) on Statistical Analysis System (SAS) software. The results 
were integrated over the crop duration to obtain the final grain yields of simulated rice crops.

\section{Estimation of radiation use efficiency (RUE)}

The model also enabled the estimation of RUE in each season by regressing biomass accumulation against cumulative absorption of radiation. Intercepts of all linear regressions were not significantly different from zero. RUE was estimated as the slope of each regression.

\section{Partitioning of relative contributions}

Simulations in which LAI and photosynthetic characteristics were independently varied (i.e. situations a and b) enabled the estimation of relative contributions of LAI $\left(\mathrm{C}_{\mathrm{L}}\right)$ and photosynthetic characteristics $\left(\mathrm{C}_{\mathrm{p}}\right)$ to yield and RUE reductions under water stress.

$$
\begin{aligned}
& C_{L}=\left[\left(Y_{i}-Y_{a}\right) /\left(Y_{i}-Y_{c}\right)\right] \times 100 \\
& C_{r^{\prime}}=\left[\left(Y_{n}-Y_{c}\right) /\left(Y_{i}-Y_{c}\right)\right] \times 100
\end{aligned}
$$

where, $\mathrm{Y}$ denotes simulated yields with the subscripts $\mathrm{i}$, a and $\mathrm{c}$ referring respectively to irrigated, LAI reduced (i.e. situation a) and both LAI and photosynthetic characteristics reduced (i.e. situation c) simulations.

$\mathrm{C}_{\mathrm{L}}$ and $\mathrm{C}_{\mathrm{p}}$ for reduction in RUE under drought were also computed using similar equations with $\mathrm{Y}$ replaced by the corresponding RUE values.

Estimation of the above contributions are dependent on the sequence of stress responses. It is well-established that leaf area expansion is more sensitive to water stress than is photosynthesis.32.33 Therefore, it was assumed that when water stress develops gradually, the reduction of LAI occurs first and the modification of photosynthetic characteristics occur subsequently.

\section{RESULTS AND DISCUSSION}

\section{Comparison of simulated and actual rice yields under irrigation}

Performance of the basic model was checked by comparing the simulated rice yields under irrigation with the actual yields (Fig. 3) obtained for irrigated rice in the Mahaweli 'H' area (e.g. Kalawewa). There was satisfactory agreement between the patterns of inter-seasonal variation of simulated and actual yields. Except for the period between yala, 1987 and maha, 1989, the model systematically underestimated the maha yields and overestimated the yala yields. The underestimation of maha yields was probably because the actual average yield 
includes yields from varieties which have a lifespan longer than the 4 months specified in the model. Very often farmers grow longer duration ( $>4$ months) varieties when irrigation is assured. These longer duration varieties have a greater yield potential thus creating the underestimation in model performance when a 4-month variety is used in the simulations. The overestimation of yala yields occurred most probably because of the water deficits experienced by actual yala crops. Even in major irrigation schemes, rice crops may be water-stressed due to delayed or less-frequent irrigation due to lack of irrigation water. The consequent decreases in actual yala yields probably caused the overestimation by the model. Moreover, the present model considers only the effects of soil water stress. In fact, a reduction in atmospheric moisture (i.e. an increase in atmospheric saturation vapour pressure deficit) can also cause stomatal closure and thereby a reduction in crop photosynthesis leading to a reduction in actual yield.

\section{ACTUAL \& PREDICTED RICE, YIELDS UNDER IRRIGATION (i.e. no stress)}

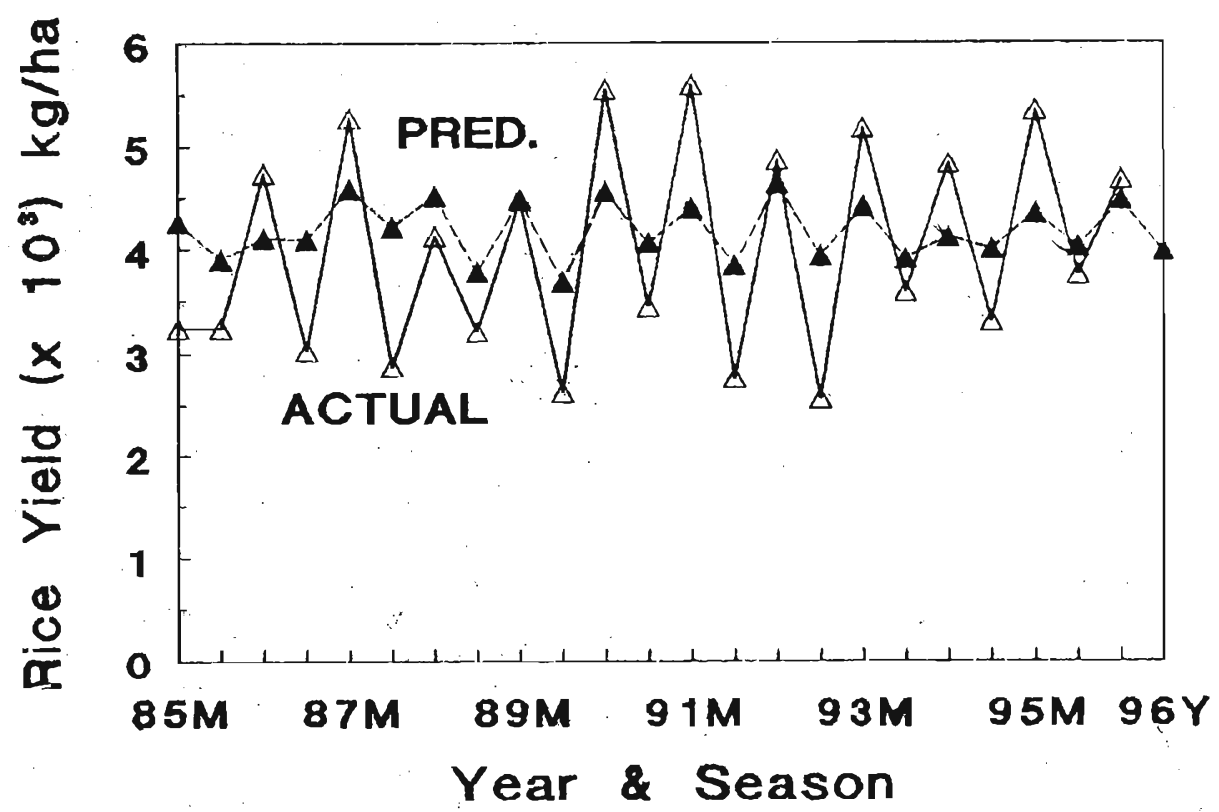

Figure 3: Comparison of simulated rice yields uncler irrigation with actual yields for irrigated rice in Mahaweli ' $H$ ' region.

M - maha season; $\mathrm{Y}$ - yala season.

The simulated rice yields in the absence of water stress ranged from 4.33 to $4.97 \mathrm{mt} \mathrm{ha}^{-1}$ (mean=4.72 $\mathrm{mt} \mathrm{ha}^{-1}$ ) in maha and from 3.85 to $4.48 \mathrm{mt} \mathrm{ha.}^{-2}$ (mean=4.19 $\mathrm{mt} \mathrm{ha}^{-1}$ ) in yala (Figs. 3 and 5 ). The respective coefficients of variation $(\mathrm{CV})$ of the above unstressed yields were $5.32 \%$ and $3.84 \%$. 


\section{Onset and magnitude of drought}

The simulated seasonal variation of root zone water content during the 12-year period of simulation is shown in Fig. 4. The time of onset and magnitude of drought is indicated when SWC decreases below SWC $_{c r}$ (i.e. $60 \%$ available water - $0.412 \mathrm{~m}^{3} / \mathrm{m}^{3}$-). In a majority of maha seasons, water stress did not occur until the crop reached the grain filling stage (i.e. 90 days after planting). Water stress did not occur at all during certain maha seasons (e.g. 1994). In contrast, during the yala season, the onset of drought started at or before the end of the vegetative stage (i.e. 45 days after planting). Therefore, unless supplementary irrigation is provided, the yala rice crops experience a greater degree of water stress over a longer duration of their lifespan as compared to the maha crops.

\section{Simulated rice yields under water stress}

Under water-stressed conditions, when both photosynthetic characteristics and LAI were modified (i.e. situation $\mathrm{c}$ ), the simulated overall yield reduction ranged from 3 to $64 \%$ in maha and 23 to $81 \%$ in yala (Fig. 5). The respective mean yields for the 12-year period under simulation were $3.34 \mathrm{mt} \mathrm{ha}^{-1}$ (maha) and $1.73 \mathrm{mtha}^{-1}$ (yala). The yield reductions were greater in yala because of the earlier onset and greater magnitude of water deficits (Fig. 4). Besides, inter-seasonal variability of yield, as indicated by the CV, was much higher (i.e. $27.78 \%$ and $36.29 \%$ respectively for maha and yala) than under unstressed conditions. The frequency of low yields (i.e. $<2 \mathrm{mt} \mathrm{ha}^{-1}$ ) was greater in yala (in 10 seasons out 12 ) than in maha (once in 12 seasons).

\section{Variation of radiation use efficiency (RUE) under irrigated and drought conditions}

In the absence of water stress, the mean estimated RUE was 1.21 and $1.19 \mathrm{~g} \mathrm{MJ}$ in maha and yala respectively (Fig. 6). Under water stress, when both LAI and photosynthetic characteristics were modified (i.e. situation $c$ ), the simulated RUE was reduced by $1-27 \%$ and $4-71 \%$ in maha and yala respectively. The respective mean RUE were $1.09 \mathrm{~g} \mathrm{MJ}^{-1}$ (maha) and $0.78 \mathrm{~g} \mathrm{MJ-1}^{\text {(yala). }}$

\section{Contributions of LAI and photosynthetic characteristics to yield and RUE reductions}

The relative contribution to yield reduction from the decrease of $\mathrm{LAI}\left(\mathrm{C}_{\mathrm{L}}\right)$ ranged from 36 to $100 \%$ (Fig. 7). Conversely, the contribution from the modification of photosynthesis, respiration and assimilate partitioning characteristics $\left(\mathrm{C}_{\mathrm{p}}\right)$ was $0-64 \%$. There was no systematic variation between maha and yala seasons in the above contributions. $C_{L}$ was greater than $C_{p}$ in a majority (i.e. 19 out of 24 ) of the seasons used in the simulations. For reduction of $R U E, C_{L}$ and $C_{p}$ were $0-73 \%$ and $27-100 \%$ respectively. In contrast to the corresponding contributions to yield reductions, $C_{p}$ was greater than $C_{L}$ in a majority (i.e. 15 out 24) of seasons. 

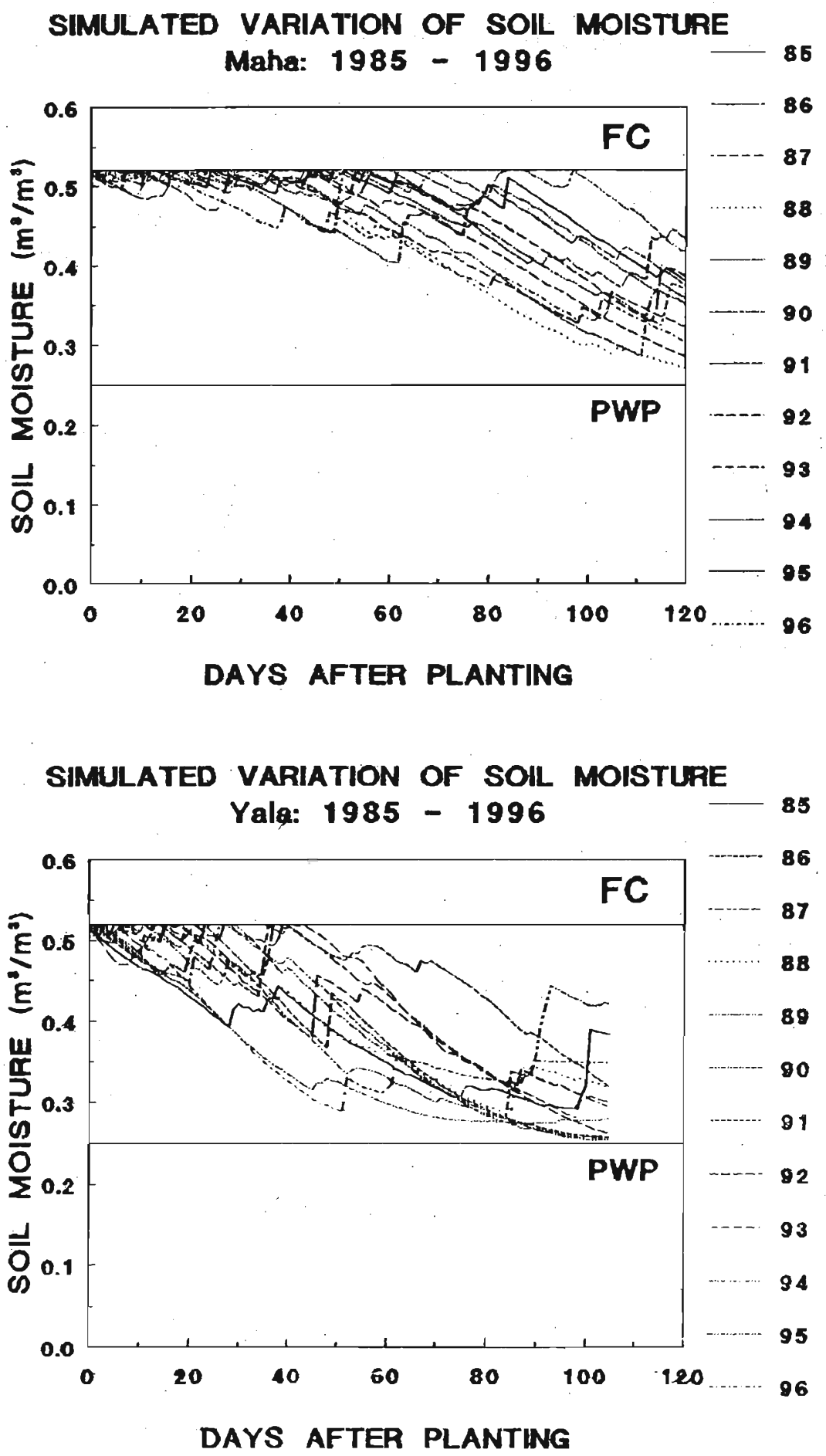

Figure 4: Simulated variation of root zone soil water content.

FC - field capacity; PWP - permanent wilting point; $0.412 \mathrm{~m}^{3} / \mathrm{m}^{3}-60 \%$ available water. 


\section{SIMULATED RICE YIELDS \\ Maha: 1985 - 96}

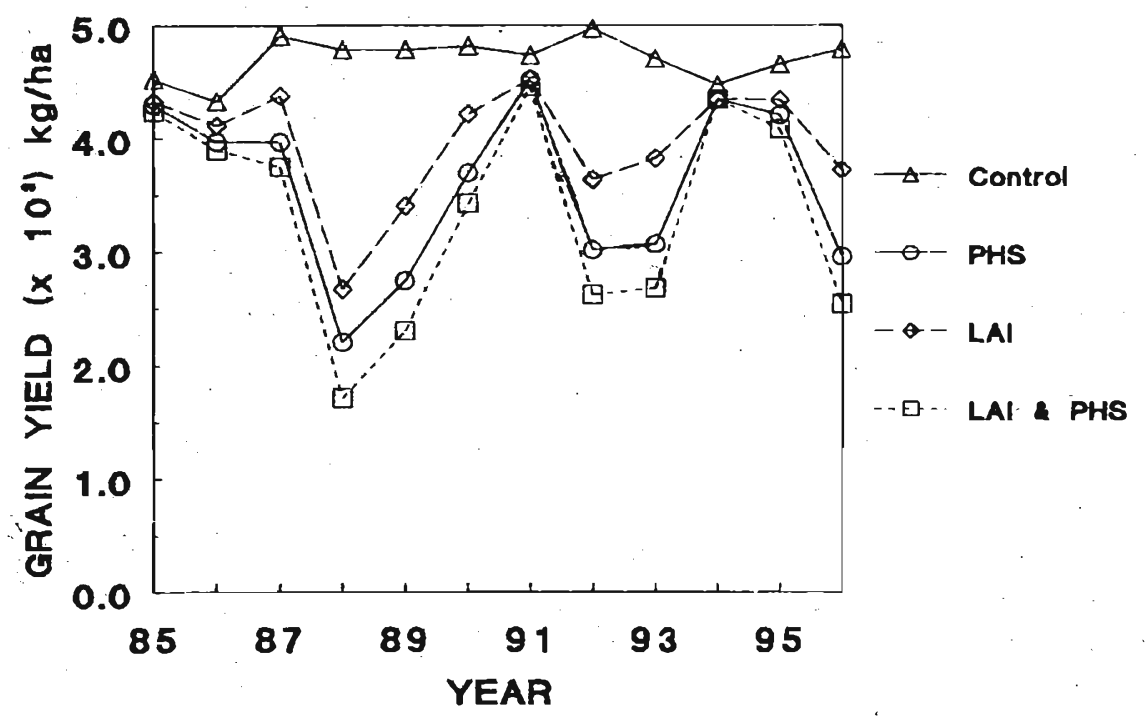

\section{SIMULATED RICE YIELDS \\ Yala: 1985 - 96}

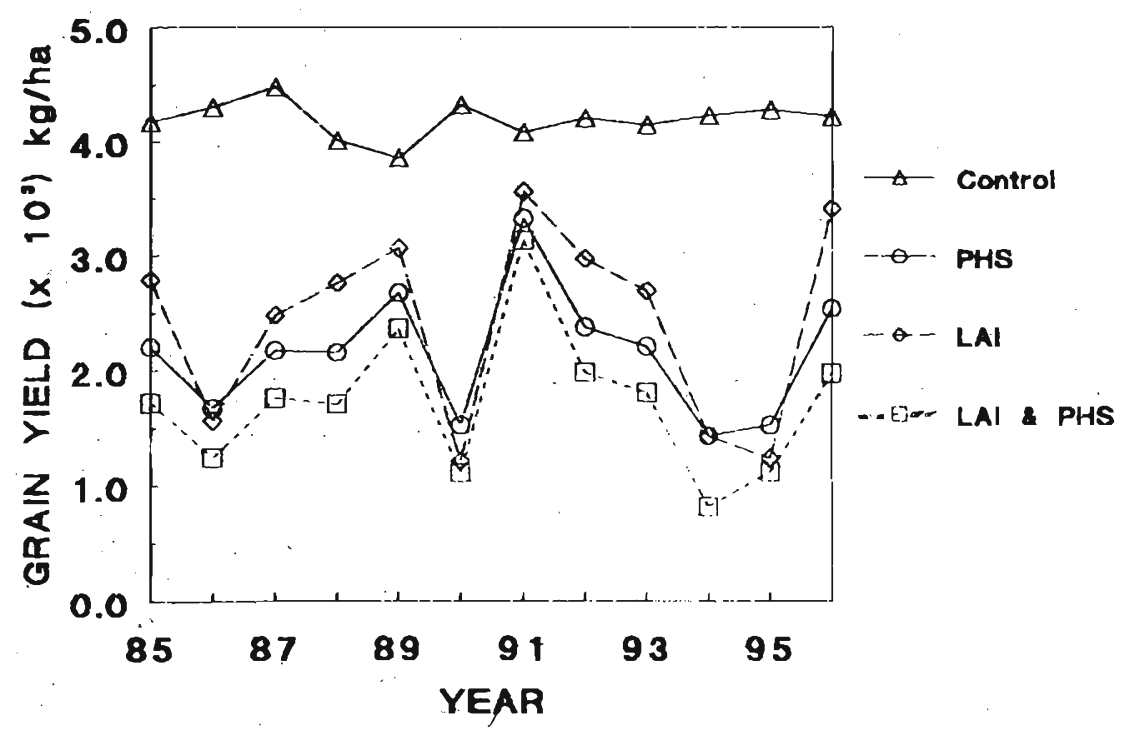

Figure 5: Simulated rice yields under irrigated and water stressed cunditions.

Control - Irrigated. PHS - Photosynthetic characteristics changed, but LAI unchanged. LAI - LAI changed, but photosynthetic characteristics unchanged. LAI \& PI-IS - Both sets of characters changed. 

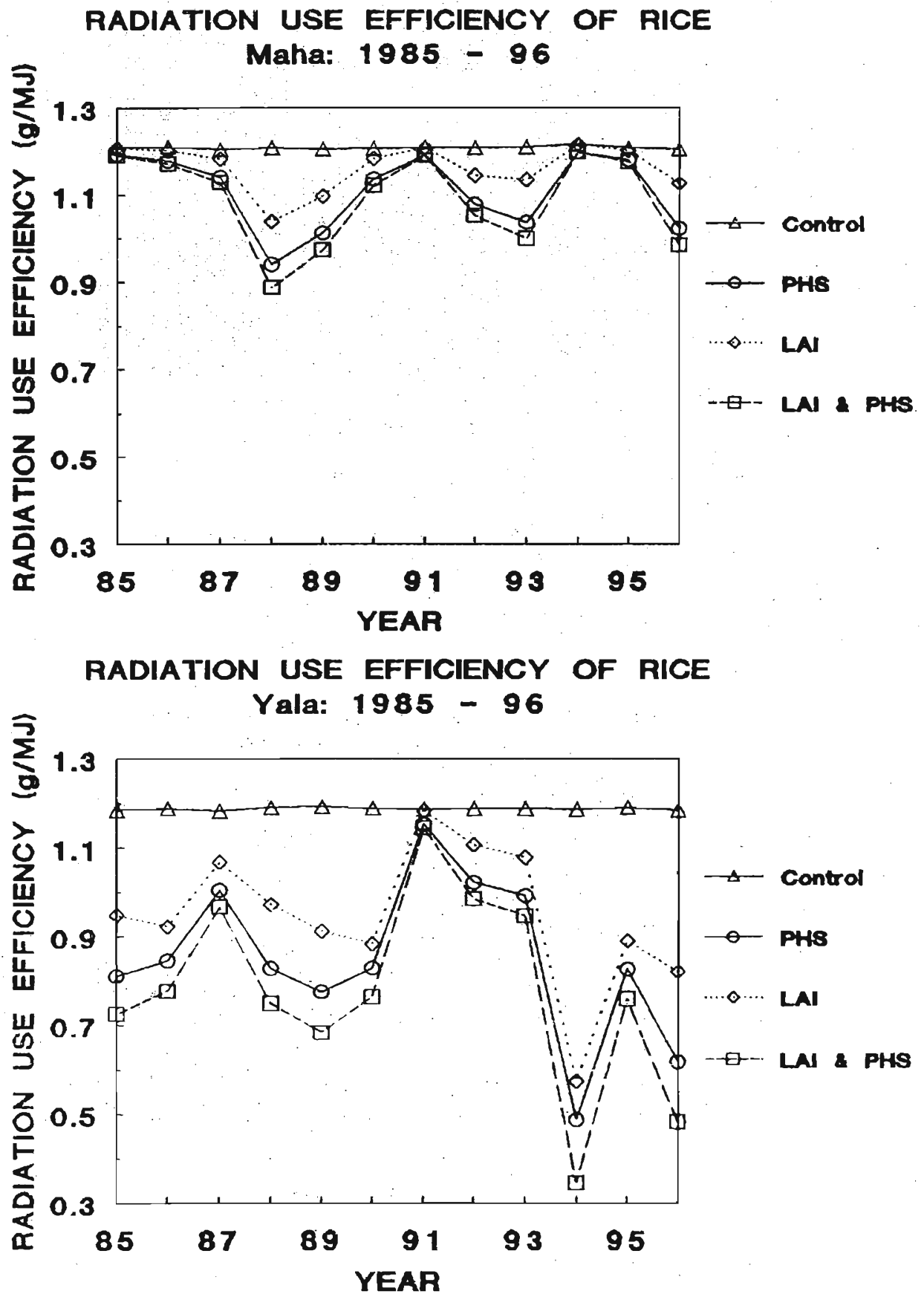

Figure 6: Simulated radiation use efficiency of rice under irrigated and water stressed conditions.

Symbols are the same as in Fig. 5. 


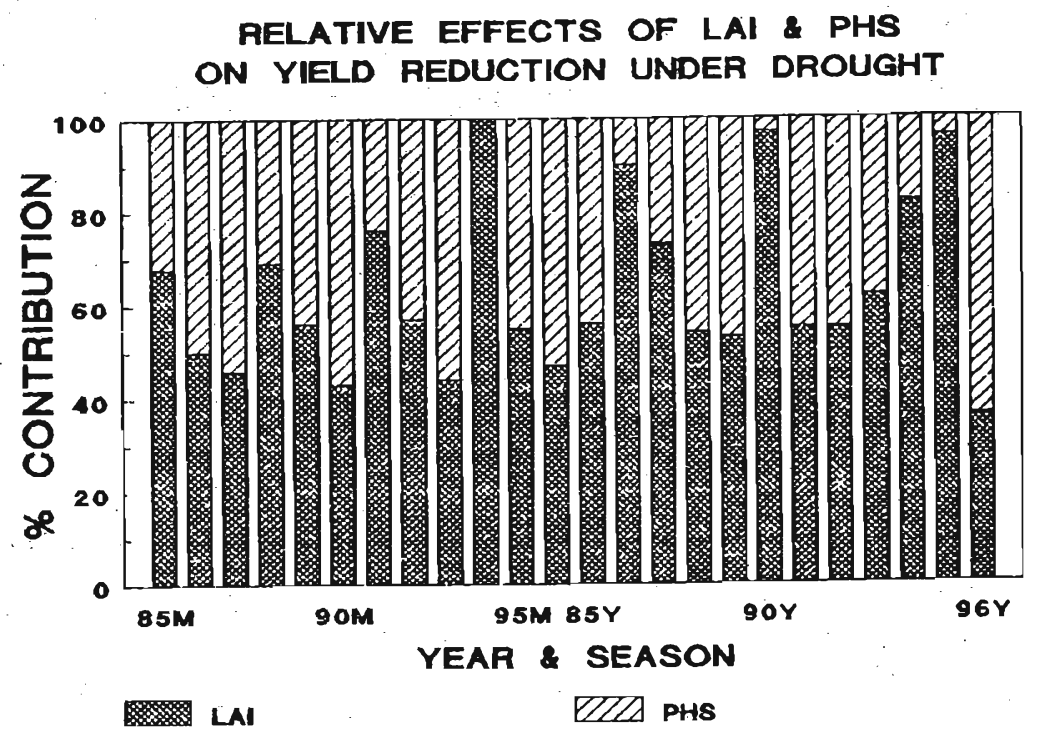

Figure 7: Contributions of LAI and photosynthetic characteristics to yield reductions under drought.

LAI - \% contribution from reduction of LAI. PHS - \% contribution from reduction of photosynthetic characteristics. M - maha. Y - yala.

\section{RELATIVE EFFECTS OF LAI \& PHS ON RUE UNDER DROUGHT}

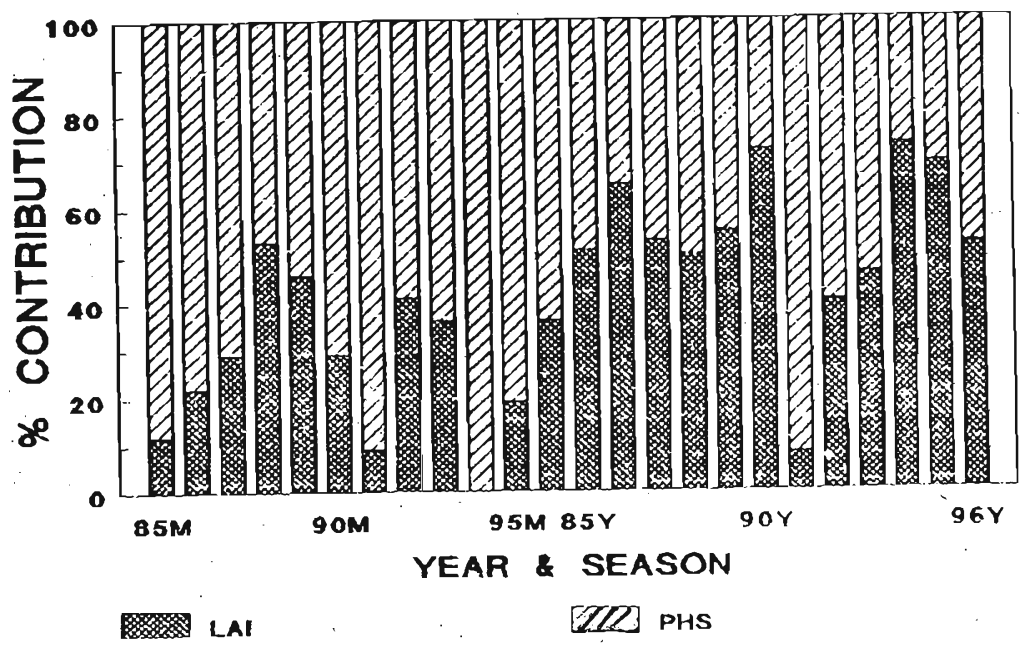

Figure 8: Contributions of LAI and photosynthetic characteristics to reductions of RUE under drought.

Symbols are the same as in Fig. 7. 


\section{Implications and guidelines for breeding drought tolerant rice varie- ties}

Estimated contributions to yield reductions from decreases of LAI $\left(\mathrm{C}_{\mathrm{L}}\right)$ and carbon assimilation characteristcs $\left(\mathrm{C}_{\mathrm{p}}\right)$, show their relative importance in breeding rice varieities which would be tolerant to the type of drought experienced in the low-country dry zone $\left(\mathrm{DL}_{1}\right)$ of Sri Lanka. The greater magnitude of $\mathrm{C}_{\mathrm{L}}$ in a majority of seasons, indicate that maintenance of a higher leaf area even under drought is more desirable than maintaining a higher photosynthetic rate. This agrees with the contention of Watson ${ }^{34}$ which is reiterated by Passioura et al. 7 that the size of the photosynthetic apparatus (i.e. leaf area) makes a greater contribution than its efficiency (i.e. photosynthetic rate) in yield determination. Therefore, mechanisms which enable the crop to maintain a greater LAI even under increasing water stress should be incorporated through breeding. Such mechanisms include osmotic adjustment, $35,36,37$ lower cell wall extensibility (i.e. lower reduction of cell expansion per unit decrease of cellular turgor) and lower threshold turgor (i.e. lower level of cellular turgor potential at which cell. expansion ceases). ${ }^{38}$

However, maintaining a greater leaf area under drought would entail the potential danger of incurring higher rates of transpiration especially under conditions for high atmospheric demand (i.e. higher levels of solar radiation, temperature and vapour pressure deficit). Therefore, mechanisms which prevent excessive transpiration rates when the atmospheric demand is high, but allow maximum carbon assimilation when the atmospheric demand is lower, need to be incorporated through breeding. Greater sensitivity of stomata to both soil and atmospheric water deficits and the capacity for reversible leaf movement and rolling are such characters. ${ }^{36}$

On the other hand, if the breeding objective is to maximize RUE under drought (e.g. in environments which experience frequent cloudy weather), a greater emphasis should be placed on maintaining higher rates of photosynthesis and lower rates of respiration even under increasing water deficits.

\section{Further improvements to be made in the model}

Accuracy of the predictions made using the present model could be improved further by incorporating two additional effects as sub-models. One effect is the variation of dry matter partitioning in response to water stress. Usually, more assimilates are partitioned to roots under drought. This could have two opposing effects on the yield: One is that greater root growth could increase water absorption (if there is water in the deeper soil layers) and alleviate the effects of water stress leading to a positive effect on the yield. However, as greater root growth would occur at the expense of shoot growth, a reduction of shoot growth 
would ultimately lead to a reduction in crop photosynthesis which would have a negative effect on yield. Modelling these effects would be difficult and would make the model cumbersome to use because of the additional parameters involved.

The second effect that could be included is the effect of temperature on photosynthesis and respiration. In the present model, photosynthesis is as sumed to depend solely on the intensity of absorbed radiation. However, the parameters of the light response curve and the fraction of assimilates used for respiration could respond to variation in temperature as well. Hence, model predictions could be improved by incorporating the effect of temperature variations. In the present model, the assumption was made that the temperature variations that occur in the dry zone of Sri Lanka are not significant enough to cause substantial variations in the model parameters.

\section{References}

1. Pathinayake B.D., Nugaliyadde L. \& Sandanayake C.A. (1991). Direct seeding practices for rice in Sri Lanka. In: Direct seeded flooded rice in the tropics. pp. 77-90. International Rice Research Institute, Philippines.

2. IRRI (1982). Drought resistance in crops with emphasis on rice. International Rice Research Institute, Philippines. $414 \mathrm{pp}$.

3. Ingram K.T. (1995). Preface. In: Rainfed lowland rice: agricultural research. for high-risk environments. (Ed. K.T. Ingram). pp. vi-vii. Internationa] Rice Research Institute, Philippines.

4. Cassman K.G. (1994). Introduction. In: Breaking the yield barrier. (Ed. K.G. Cassman). pp. 3-4. International Rice Research Institute, Philippines.

5. Rothschild, G. (1995). Foreword. In: Rainfed lowland rice: agricultural research for high-risk environinents. (Ed. K.T. Ingram). pp. v. International Rice Research Institute, Philippines.

6. OrToole J.C. \& Chang T.T. (1979). Drought resistance in cereals -rice: a case study. In: Stress physiology in crop plants. (Eds. H. Mussell and R.C. Staples). pp. 373-405. John Wiley, New York.

7. Passioura J.B., Condon A.G. \& Richards R.A. (1993). Water deficits, the development of leaf area and crop productivity. In: Water deficits: plant responses from cell to community. (Eds. J.A.C. Smith \& H. Griffiths). pp. 253-265. Bios Scientific Publishers, Oxford, U.K. 
8. Sinha S.K., Khanna-Chopra R., Aggarwal P.K., Chaturvedi G.S. \& Koundal K.R. (1982). Drought resistance in crops with emphasis on rice. pp. 153-169. International Rice Research Institute, Philippines.

9. Lawlor D.W. (1995). The effects of water deficit on photosynthesis. In: Environment and plant metabolism: flexibility and acclimation. (Ed. N. Smirnoff). pp. 129-160. Bios Scientific Publishers, Oxford, U.K.

10. Van Keulen H. \& Wolf J. (1986). Modelling agricultural production: weather, soils and crops. Pudoc, Wageningen, The Netherlands. 479 pp.

11. Panabokke C.R. \& Hussan N. (1980). The application of agrometeorology to some aspects of rice research in Sri Lanka. In: Agrometeorology of the rice crop. pp. 115-120. International Rice Research Institute, Philippines.

12. Yoshida S. (1981). Fundamentals of rice crop science. International Rice Research Institute, Philippines. 269 pp.

13. List R.J. (1968). Smithsonian meteorological tables. Smithsonian Institute Press, Washington.

14. Samuel T.D.M.A. (1991). Estimation of global radiation in Sri Lanka. Solar Energy 47: 333-337.

15. Szeicz G. (1974). Solar radiation for plant growth. Journal of applied ecology 11: 617-636.

16. Monsi M. \& Saeki T. (1953). The light factor in plant communities and its significance for dry-matter production. Japanese Journal of Botany 14: 2252 .

17. Monteith J.L. (1981). Does light limit crop production? In: Physiological processes limiting plant productivity. (Ed. C.B. Johnson). pp. 23-38. Butterworths, London.

18. Monteith J.L. \& Unsworth M.H. (1990). Principles of environmental physics. 2nd edition. Edward Arnold, U.K. 291 pp.

19. Hunt R. (1982). Plant growth curves: the functional approach to plant growth analysis. Edward Arnold, U.K. 248 pp.

20. Penning de Vries F.W.T., Jansen D.M., ten Berge H.F.M. \& Bakema A. (1989). Simulation of ecophysiological processes of growth in several annual crops. Simulation Monograph No. 29, Pudoc, Wageningen. 271 pp. 
21. Tanaka A. \& Yamaguchi J. (1968). The growth efficiency in relation to the growth of the rice plant. Soil Science and Plant Nutrition 14: 110-116.

22. Yamaguchi J. (1978). Respiration and growth efficiency in relation to crop productivity. Journal of the Faculty of Agriculture, Hokkaido Unversity 59: 59-129.

23. Murata Y. \& Matsushima S. (1975). Rice. In: Crop physiology. (Ed. L.T. Evans). pp. 73-99. Cambridge University Press, Cambridge.

24. Cock J.H. \& Yoshida S. (1972). Accumulation of ${ }^{14} \mathrm{C}$-labelled carbohydrate before flowering and the subsequent redistribution and respiration in the rice plant. Proceedings of the Crop Science Society, Japan 41: 226-234.

25. Panabokke C.R. (1978). Rice soils of Sri Lanka. In: Soils and rice. pp. 19-33. International Rice Research Institute, Philippines.

26. Driessen P.M. (1986). The water balance of the soil. In: Modelling agricultural production: weather, soils and crops. (Ed. H. Van Keulen \& J. Wolf). pp. 76-116. Pudoc, Wageningen, The Netherlands.

27. Ritchie J.T. (1972). Model for predicting evapotranspiration from a row crop with incomplete cover. Water Resources Research 8: 1208-1213.

28. Doorenbos J., Kassam A.H., Bentvelder C. \& Uittenboogaard G. (1978). Yield response to water. U.N. Economic Commission (West Asia), Rome.

29. Lawlor D.W. \& Uprety D.C. (1993). Effects of water stress on photosynthesis of crops and the biochemical mechanism. In: Photosynthesis: photoreactions to plant productivity. (Eds. Y.P. Abrol, P. Mohanty, \& Govindjee). pp. 419-449. Oxford \& IBH Publishing Co., New Delli, India.

30. Krampitz M.J., Klug K. \& Fock H.P. (1984). Rates of photosynthetic $\mathrm{CO}_{2}$ evolution and dark respiration in water-stressed sunflower and bean leaves. Photosynthetica 18: 322-328.

31. Lawlor D.W. (1976). Water stress induced changes in photosynthesis, photorespiration, respiration and $\mathrm{CO}_{2}$ compensation concentration in wheat. Photosynthetica 10: 378-387.

32. Taiz L. \& Zeiger E. (1991). Plant physiology. Benjamin/Cummings Publishing Co., California. 559 pp. 
33. Turner N.C. (1986). Crop water deficits: a decade of progress. Advances in Agronomy 39: 1-51.

34. Watson D.J. (1952). Physiological basis for variation in yield. Advances in. Agronomy 4: 101-145.

35. Steponkus P.L., Shahan K.W. \& Cutler J.M. (1982). Osmotic adjustment in rice. In: Drought resistance in crops with emphasis on rice. pp. 181-194. International Rice Research Institute, Philippines.

36. Turner, N.C. (1982). The role of shoot characteristics n drought resistance of crop plants. In:Drought resistance in crops with emphasis on rice. pp. 115134. International Rice Research Institute, Philippines.

37. Lilley J.M. \& Ludlow M.M. (1996). Expression of osmotic adjustment and dehydration tolerance in diverse rice lines. Field Crops Research 48: 185 197.

38. Lockhart J.A. (1965), An analysis of irreversible plant cell elongation. Journal of Theoretical Biology 8: 264-275. 